\title{
BIOLOGICAL CONTROL OF TOMATO ROOT-ROTS USING TRICHODERMA SPP.
}

\author{
M.A. Awad ${ }^{(1)}$, E.Z. Khlifa(1), M. Z. El-Fouly(2), Azza A.M. Shahin ${ }^{(2)}$, \\ Heba A. El-Bialy ${ }^{(2)}$ and Shimaa M. Fahmy ${ }^{(2)}$ \\ ${ }^{(1)}$ Faculty of Agriculture, University Minufiya , Egypt. \\ (2) National Center for Radiation Research and Technology (NCRRT), Radiation Microbiology \\ Department, Atomic Energy Authority, Cairo, Egypt. \\ elbialyheba@yahoo.com
}

Received: Mar. 7, 2017

Accepted: Mar. 28, 2017

\begin{abstract}
Two hundred and fifty nine fungal pathogens were isolated from the diseased tomato by root-rots which collected from six governorates; Baheira, Giza, Ismailiya, Qalubiya, Qena and Sharkiya, roots during 2012 and 2013 seasons. Alternaria solani, Fuarium oxysporum and Rhizoctoina solani were the most frequent fungal that isolated from infected tomato root. Twenty fungal isolates were selected according to isolation frequency and geographic distributions. Their virulence and pathogenicity was individuality tested against healthy and informal tomato root cultivar (GF12). Pathogenicity experiment showed the aggressive fungal pathogens either for wounded tomato plants or unwounded ones are Alternaria solani No.1, Fuarium oxysporum No.1 and Rhizoctoina solani. All tested bioagents were decreased the linear growth of $A$. solani. The growth reduction percentages ranged between 85.2 and $46.7 \%$. $R$. solani was more sensitive to twenty tested bioagents since its linear growth declined clearly compared to other pathogens. The over growth phenomena of Trichoderma bioagent was more clear in R. solani than other tested fungal pathogens. Antagonistic studies under greenhouse conditions concluded the potency of $T$. harzianum $T z_{1}, T$. koningii $T k_{1}, T$. longbactrium $T I_{1}$ and $T$. viride $T d_{1}$ against of tomato root rot pathogens. Different strategies are applied to enhance the activity of these promising bioagents in an individual upcoming study.
\end{abstract}

Key word: Root-rot fungi; Tomato, Trichoderma, Biological control

\section{INTRODUCTION}

Tomato ( Lycopersicon esculantum Mill), which follow solanaceae family, is the most popular and economic vegetable crops in whole parts of the world for its high nutritional value and richness in Vitamins $A$ and $C$ and realy for its multiplicity uses (ALElzerjawi, 2015). Tomato plants are affected by several diseases including root-rot and or damping-off disease symptoms caused by Rhizoctonia solani, Fusarium oxysporum and Alternaria solani which cause serious diseases and finally reduced crop yield (EIMougy et al., 2012).

Biological control for soil-borne pathogens by antagonistic microorganisms is one of significant challenges due to difficulties to be controlled with specific fungicides and it was usually have not any toxic residues in food chains, safe, while chemicals fungeicides might results in soil contamination or other harmful effects. Additionally, biological control of soil-borne plant pathogens is a potential alternative to the use of chemical pesticides, which have already been proved to be harmful to the environment (Gaigole et al., 2011). Antagonists of phytopathogenic fungi have been used to control plant diseases, and $90 \%$ of such applications have been carried out with different strains of the fungus Trichoderma. Most of these strains are classified as imperfect fungi since they have no known sexual stage (Benítez et al., 2004). These fungi have attracted attention because of their multiple actions against various soil borne plant pathogens. Proposed mechanisms for biocontrol are: stimulation of the defensive mechanisms of 
the plants, competition for the substrate as well as antibiosis by the production of antifungal metabolites and mycoparasitism by the action of cell-wall degrading enzymes. Chitinolytic and glucanolytic enzyme systems involved in the mycoparasitism of Trichoderma isolates have been investigated in detail and are well characterized (Harman et al., 2004). Trichoderma spp have shown biocontrol activity against damping off and root rot disease and gave high yield of tomato (Zaghloul et al., 2007).

\section{MATERIAL AND METHODS}

\section{Collection of infected plant materials.}

Naturally infected tomato root showing root diseases symptoms were collected from different governorates of Egypt; Beheira, Giza, Ismailiya, Qalubiya, Qena and Sharkiya.

\section{Isolation and purification of fungal pathogens causing root rot disease.}

The infected roots were cut into small pieces, washed thoroughly with running tap water to remove any adhering soil particles and surface sterilized as standard protocols. The surface sterilized samples were then transferred onto Potato Dextrose Agar medium (PDA) containing antibacterial antibiotic to avoid the bacterial contamination. The inoculated plates were then incubated at $25^{\circ} \mathrm{C}$ for 3-7 days and examined daily for the occurrence of fungal growth. The developed fungal colonies were picked up and purified using single spore or hyphal tip techniques.

The pure cultures of the growing fungi were then examined microscopically and identified at National Center for Radiation Research and Technology, Radiation Microbiology Department according to the methods and identification key of imperfect fungi (Barnett and Hunter, 1972 and Domsch et al., 1980).

\section{Isolation and identification of biological control agents from soil and rhizosphere.}

Rhizosphere soil samples were selected from tomato fields by uprooting the infected plants with great care to obtain most of the intact root system. The selected root system was shaken gently to get rid of excess soil particles. The sample were kept in sterile plastic bags and stored at $4^{\circ} \mathrm{C}$ until performing the isolation process. Isolation of Trichoderma species was performed using Trichoderma Selective Medium (TSM) (Elad et al., 1981).

The developed colonies were marked and purified according to standard methods and maintained on PDA slants at $4^{\circ} \mathrm{C}$. Then, they are identified to species level according to the identification key adopted by Rifai (1969) and Bissett (1991).

\section{Pathogenicity test and disease assessments.}

Twenty fungal pathogens were selected according to isolation frequency and geographic distributions. They are three isolates of Fusarium oxysporum and Gibberella godonii, two isolates of Alternaria sp., A. solani, A. chlamydosporum and $F$. chlamydosporum and one isolate of $F$. semitectum, Rhizoctoina sp., $R$. solani Camarosporum tassi, Paecilomyces variotii and Sclerotinia $s p$. their pathogenicity against mature roots of the commercial tomato cultivar; GF12 was tested under greenhouse conditions.

Seedlings were uprooted from the soil 8 days after sowing. Their roots were washed free of soil and wounded with sterilized blade or kept unwounded. They dipped in spore suspension of fungal pathogens with concentration about $2 \times 10^{6}$ spore $/ \mathrm{ml}$ for 2 min. One group of tomato seedlings is maintained under the same conditions with dipping in sterilized saline and served as control. Seedlings were then transplanted $(3$ replicates $\times$ five per pot) to $700-\mathrm{ml}$ pots filled with peat moss soil. The inoculated 
seedlings were maintained in the greenhouse at $25-28^{\circ} \mathrm{C}$ in a natural daylight regime. The appearance of typical disease symptoms such as wilting and/or root rot on grown seedlings were recorded after 35 days.

Root rot and wilt severity were estimated using a rating scale of $(0-5)$ on the basis of root discoloration or leaf yellowing as following:

$0=$ neither root discoloration nor leaf yellowing.

$1=1-25 \%$ root discoloration or one leaf yellowing

$2=26-50 \%$ root discoloration or more than one leaf yellowing,

$3=51-75 \%$ root discoloration plus one leaf wilted, $4=$ up to $76 \%$ root discoloration or more than one leaf wilted and $5=$ completely dead plants.

Disease severity index (DSI) described by Abdel- Monaim et al. (2012) was adapted and calculated as following:

Disease index $=$

$\sum$ (rating number $x$ No. of plants in the rating) $x 100$ Total number of plants $x$ the highest rating

\section{Biological control.}

\subsection{Efficiency of antagonistic Trichoderma bioagents against selected fungal pathogens under laboratory conditions.}

Twenty isolates of Trichoderma spp. were subjected against the three fungal pathogens that were selected as the most aggressive pathogens in pathogenicity experiment under greenhouse conditions (Alternaria solani, Fusarium oxysporum and Rhizoctonia solani) in dual cultures using PDA medium.

Dual cultures were incubated at $25^{\circ} \mathrm{C}$ until the mycelial growth of fungal pathogens covered the entire medium in the control treatment. After that, plates were examined and the interaction between bioagents and pathogens as antagonism, hyper parasitism, inhibition or over growth. The growth reduction of root rot fungal pathogens was determined as following equation.

Reduction (\%)= Control - Treatment/Control $\times 100$
The width of the inhibition zone between the two colonies was recorded in all treatments. Then, the percentage of inhibition of radial growth of the pathogenic fungal isolates was calculated by comparing radial growth of the colony directly opposite the bioagents colony with radial growth of that part of the colony not adjacent to the bioagents (Zhou and Reeleder, 1990).

\subsection{Efficiency of antagonistic bioagents against selected fungal pathogens under greenhouse conditions.}

The spore suspension of each antagonist was prepared according to standard methods using sterile saline. Tomato seeds were mixed thoroughly with $2 \mathrm{ml}$ of the antagonist spore suspension $\left(10^{6} \mathrm{spore} / \mathrm{ml}\right)$ in $0.1 \%$ carboxy methyl cellulose. Then, seeds were air dried for $30 \mathrm{~min}$ and directly planted. Soil was infested with each fungal pathogen growing on barely grains at the rate of $5 \mathrm{~g} / \mathrm{kg}$ soil before sowing. Infested pots were irrigated for 5 days before sowing.

Ten tomato seeds (GF12) were sown in each pot; three replicate pots were specified for each treatment in completely randomized experimental design. The experiment included the following treatments: 1) non infested soil (control), 2) soil treated with pathogen only that growing on barely grows and 3) soil infected with pathogen and planted with tomato seeds treated with antagonist. Triple compound mineral fertilizer (NPK) was added with irrigation water at the rate of $2 \mathrm{~g} / \mathrm{l}$ into two doses. Pots were kept under greenhouse conditions till the end of the experiment (Morsy et al., 2009).

\section{Statistical analysis.}

All data obtained were subjected to the proper statistical analysis for each experiment using the MSTAT statistical software. Comparisons were made following fishers LSD (0.05). 


\section{Results}

1. Isolation and identification of fungal pathogens causing tomato root rot disease.

Two hundred and fifty nine fungal pathogens were isolated from the diseased roots during 2012 and 2013 seasons. These fungi were identified according to morphological characteristics at Department of Microbiology, National Center for Radiation Research and Technology (NCRRT), Egypt and Assuit University Mycological Center (AUMC), Egypt. Results revealed in table (1) clear that Alternaria solani was the most frequent fungus that isolated from infected tomato root samples $(18.5 \%)$ followed by Rhizoctoina spp. (15.4\%) and Camarosporum tassi (11.6\%). Other fungi were also isolated with low frequency as Paecilomyces spp (1.5\%) and Sclerotinia spp. (3.9\%).

Results also elucidated the highest number of fungal pathogens causing root rot diseases were isolated from infected tomato samples that collected from Sharkiya governorate (59), followed by Giza governorate (49) whereas, the same number of isolated fungi were collected from Ismailiya and Qalubiya governorates (46). In the meanwhile, the lowest numbers of pathogenic fungi were found in Baheira governorate (26) and Qena governorate (33).

\section{Pathogenicity studies.}

Data elucidated in Table (2) showed that all selected isolates were pathogenic to tomato root, with varied degree under greenhouse conditions where the virulence of pathogenicity is clearer in wounded roots than unwounded ones. It is interesting to mention that the summation of the disease index in wounded was higher than unwounded tomato root with $10 \%$. The highest aggressive fungal pathogens were A. solani isolate No. 1 and $R$. solani followed by $F$. oxysporium isolate No.1 since they caused disease index reached $84,83.5$ and
$82.5 \%$, respectively whereas the lowest disease severity was recorded by $C$. tassi (28\%) and R. oryzae (28.5\%).

The length of root system either wounded tomato roots or unwounded is higher affected by pathogenic fungal isolates than length of shoot system. On the other hand, the fresh weight of shoot system is higher affected by pathogenic fungal pathogens than fresh root weight system.

\section{Antagonistic activity of different bioagents (Trichoderma spp.) against pathogenic fungi causing tomato root rot disease.}

\subsection{Under laboratory conditions.}

Twenty bioagents belong to Trichoderma spp; $T$. hamatum (5 strains), T. harzianum (5 strains), two strains from each of $T$. atroviride, $T$. longbactrium, $T$. reesei and $T$. viride and one strain from each of $T$. koningii and $T$. virens were isolated as previously described and their antagonistic activity was tested in an individual experiment. Three criteria are monitored under laboratory conditions; the linear growth of selected fungal pathogens causing root rot disease in the presence of these bioagents and the over growth of bioagents on the root rot causing pathogens as well as, the inhibition zone around the selected fungal pathogens.

Data in Table (3) showed that all tested bioagents decreased the linear growth of $A$. solani in different degrees. The growth reduction percentages ranged between 85.2 and $46.7 \%$. The potential bioagents were $T$. viride $\mathrm{Td}_{1}$ and $T$. koningii $\mathrm{Tk}_{1}$ since they reduced the linear growth of $A$. solani by 85.2 and $80.8 \%$, respectively. The selected fungal pathogen, Rhizoctoina solani; was more sensitive to twenty tested bioagents since its linear growth declined clearly compared to other pathogens causing tomato root rot disease under investigation. The maximum growth inhibition (approximately 89\%) was accomplished by bioagent $T$. viride $\operatorname{Td}_{1}$. The over growth phenomena was more clear in this 
Biological control of tomato root-rots using trichoderma spp.

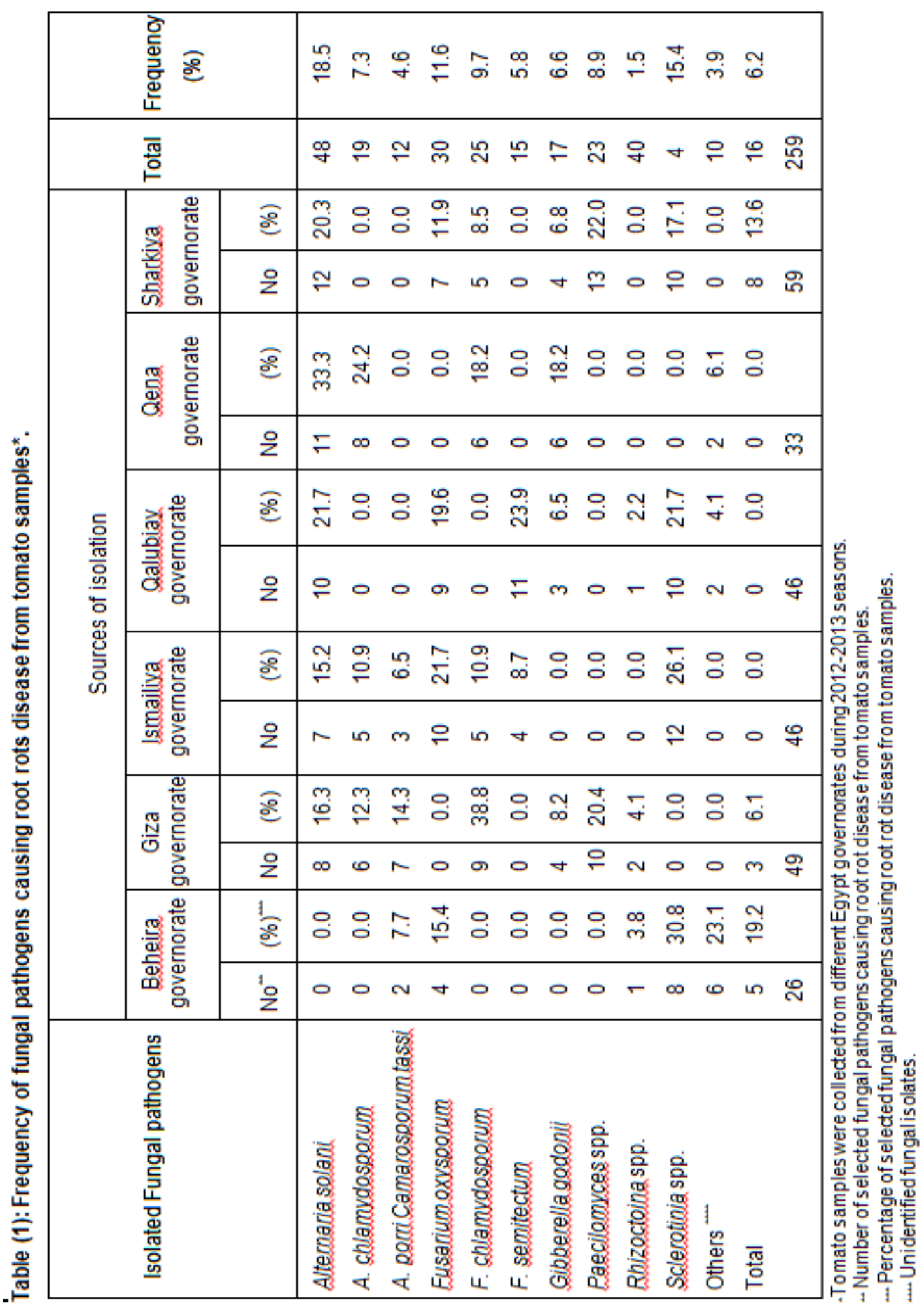


Awad, et al.,

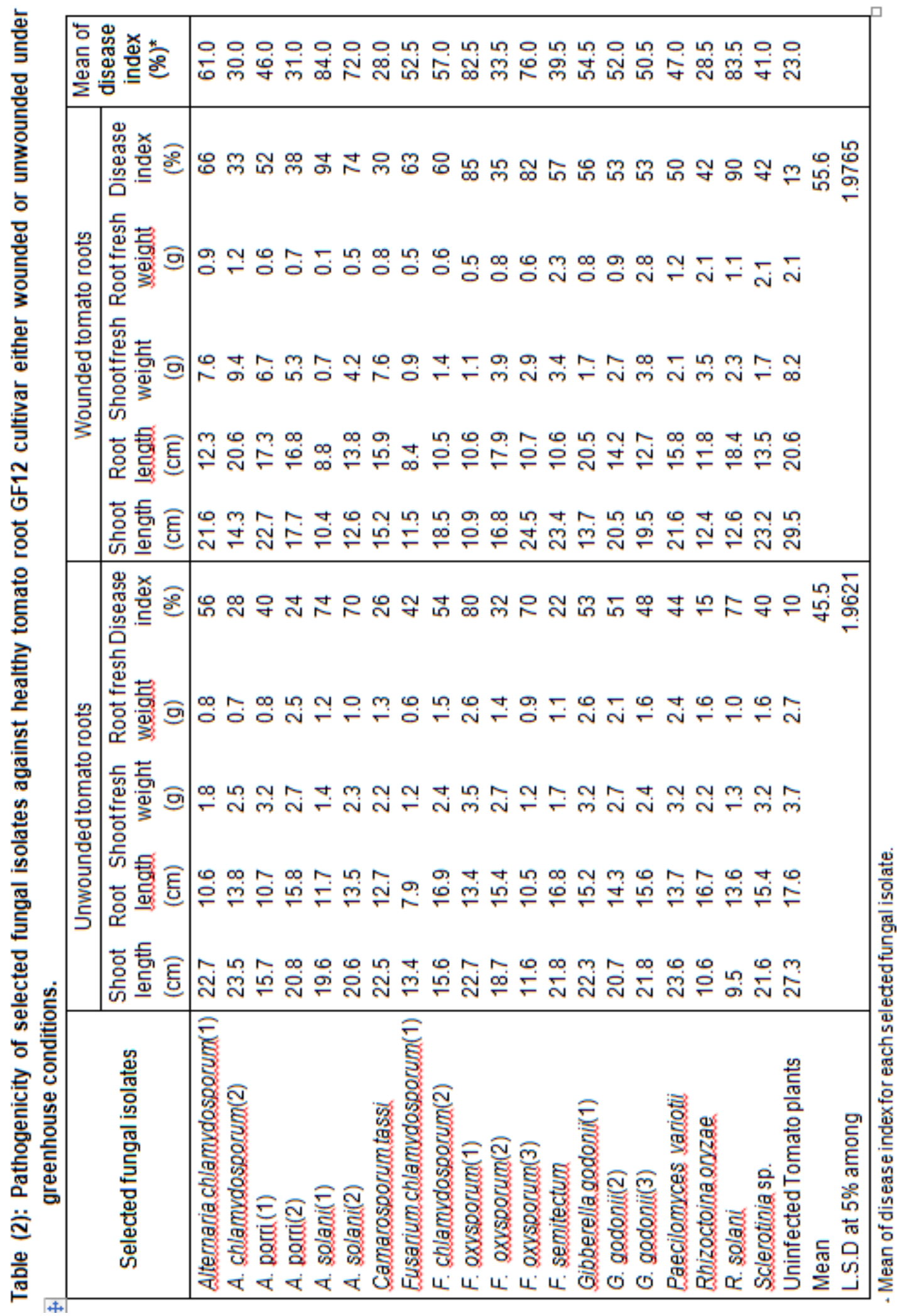




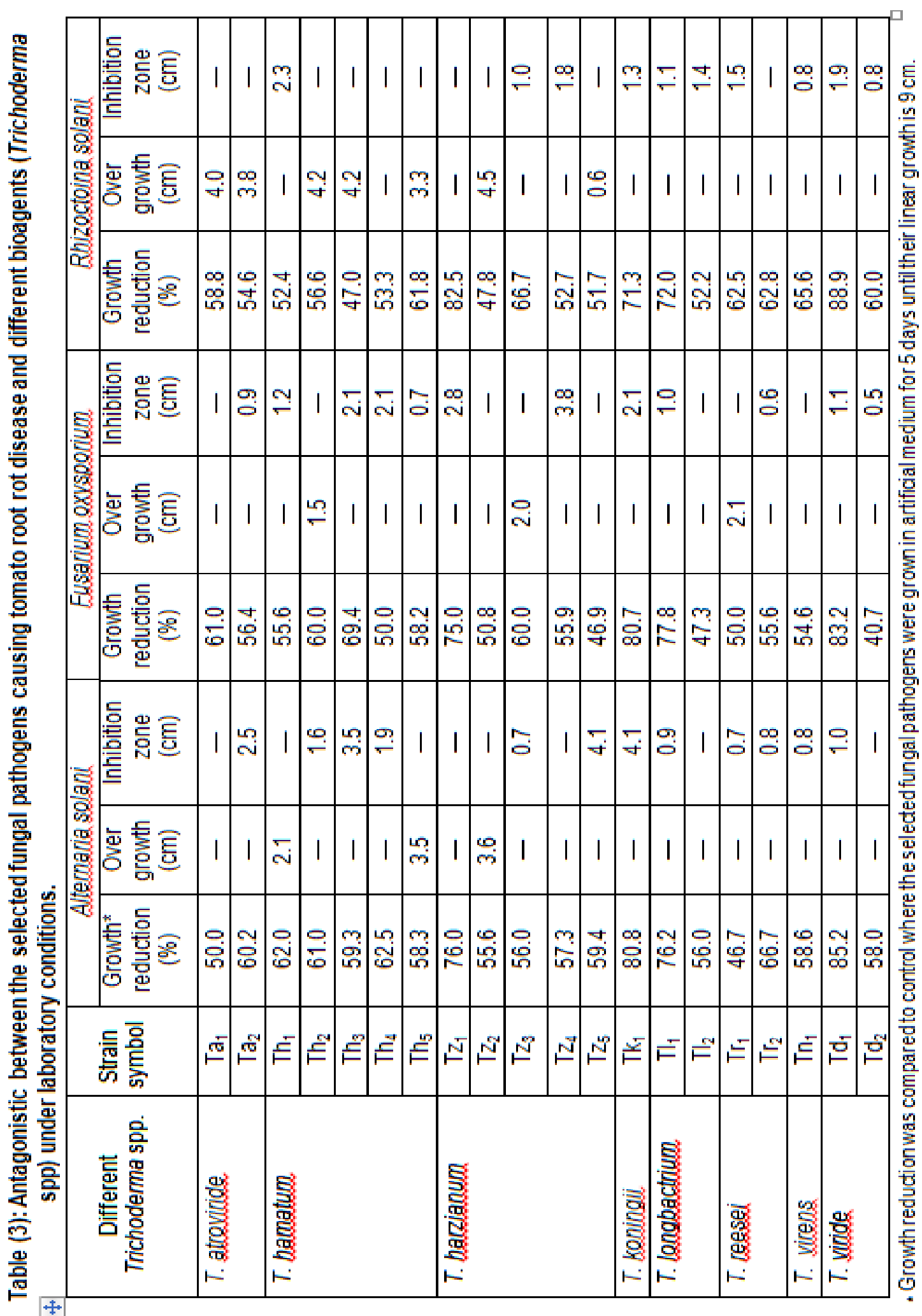


pathogen. Since seven bioagents succeeded to over growth on its mycelia with extension more than $4 \mathrm{~cm}$ accomplished by bioagents; $T$. harzianum $\mathrm{Tz}_{2}, \quad T$. hamatum $\mathrm{Th}_{2}$ and $\mathrm{Th}_{3}$. It was interesting to mention that three bioagents; $T$. hamatum $\mathrm{Th}_{4}, T$. harzianum $\mathrm{Tz}_{1}$ and $T$. reesei $\mathrm{Tr}_{2}$ failed to inhibit the growth or over grow on tomato root rot causing pathogen Rhizoctoina solani. Data in Table (3) concluded that $T$. harzianum $\mathrm{Tz}_{1}, T$. koningii $\mathrm{Tk}_{1}, T$. longbactrium $\mathrm{Tl}_{1}$ and $T$. viride $\mathrm{Td}_{1}$ are the most potent bioagents for the selected tomato root rot causing pathogens; $A$. solani, $F$. oxysporum and $R$. solani under laboratory conditions.

\subsection{Under greenhouse conditions.}

Four groups of tomato seeds (GF12) were individually coated by spore suspension of bioagents; $T$. harzianum $\mathrm{Tz}_{1}$, $T$. koningii $\mathrm{Tk}_{1}, T$. longbactrium $\mathrm{Tl}_{1}$ and $T$. viride $\mathrm{Td}_{1}$. Then, each group was divided into three sub group; each sub group was cultivated in soil artificially infected with one of the selected root rot causing pathogens (Alternaria solani, Fusarium oxysporum and Rhizoctonia solani). Data in Table (4) indicated that biological control agents greatly affected root rot incidence of tomato plants "GF12 cultiver" incited by $A$. solani in compared to control, ten bioagents out of twenty are succeeded to decrease the pre emergence damping off to less than $15 \%$ compared to $40 \%$ caused when tomato seeds were not coated with any bioagents (control). Twelve bioagents succeeded to decrease the post emergence damping off of tomato plant grew in soil infected with $A$. solani.

After damping off, the percentage of survival plants ranged between 40.0 and $83.3 \%$ in comparison with $3.3 \%$ that survive when tomato seeds were not treated with any bioagents. The disease index of latter survival plants is $89 \%$ whereas all survival plants previously treated with different bioagents have less disease index, the least disease indexes; 49, 50 and $52 \%$ were achieved by tomato plants previously treated with $T$. longbactrium $\mathrm{Tl}_{1}, T$. viride $\mathrm{Td}_{1}$ and $T$. harzianum $T z_{1}$, respectively.

Generally, treatment tomato seeds (cultivar GF12) with different bioagents has a positive impact on the growth parameters of tomato plants infected with $A$. solani including root length, root fresh weight, shoot length and shoot fresh weight (Table 4). Treatment tomato seeds with different bioagents under investigation increased the root fresh weight yield, the highest yield reached thirty folds by treating tomato seeds with $T$. atroviride $\mathrm{Ta}_{1}$ and $\mathrm{Ta}_{2}$ whereas treating tomato seeds with sixteen bioagents out of twenty ones succeeded to increase shoot fresh weight by two folds or more.

Data in Table (6) revealed the same positive pattern of bioagents under investigations against $A$. solani was noticed also with $F$. oxysporum. Treating the tomato seeds with different bioagents greatly decreased the pre-emergence and post emergence damping off caused by $F$. oxysporum. The least percentage of preemergence damping off was achieved by tomato plants previously treated with $T$. longbactrium $\mathrm{Tl}_{1}$ (3.3\%) compared to control $(43.3 \%)$ whereas the least percentage of post-emergence damping off was observed by tomato plants previously treated with $T$. hamatum $\mathrm{Th}_{3}$ and $\mathrm{Th}_{5}(3.3 \%)$ in comparison with control (33.3\%). The number of survival plants that treated with different bioagents as well as their percentages are doubled and/or more than untreated tomato seeds. Similarly, after biological control treatment with different Trichoderma spp the disease index of survival plants declined by more two thirds.

Table (5) also revealed that, treatmed of tomato seeds cultivar (GF12) with different Trichoderma spp improves growth characters in significant quantities. About half of tested bioagents nearly doubled the root and shoot length compared with control. The highest root fresh weight was achieved by survival tomato plants previously treated 


\begin{tabular}{|c|c|c|}
\hline \multirow{4}{*}{ 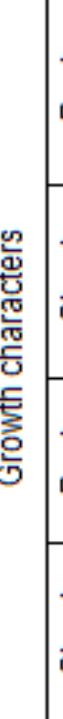 } & \multirow{2}{*}{ 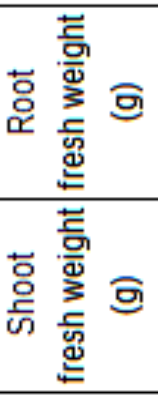 } & 응 \\
\hline & & 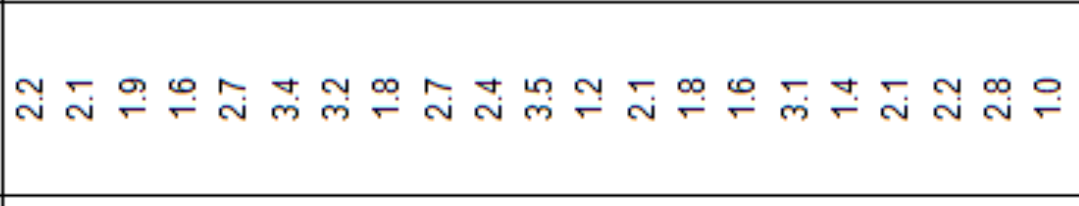 \\
\hline & 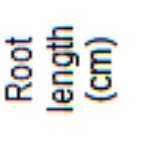 & 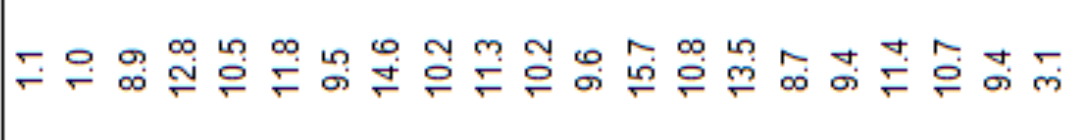 \\
\hline & 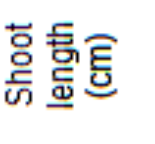 & 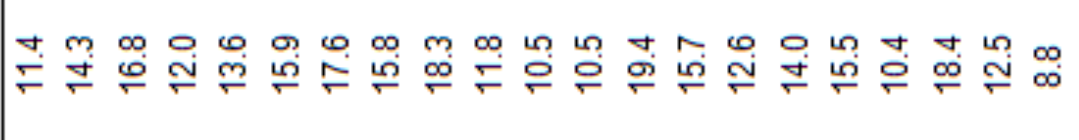 \\
\hline & 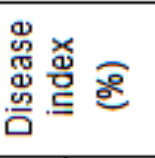 & ※ \\
\hline$\frac{2}{\bar{y}}$ & 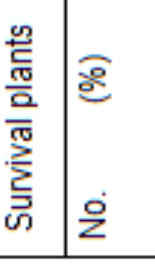 & 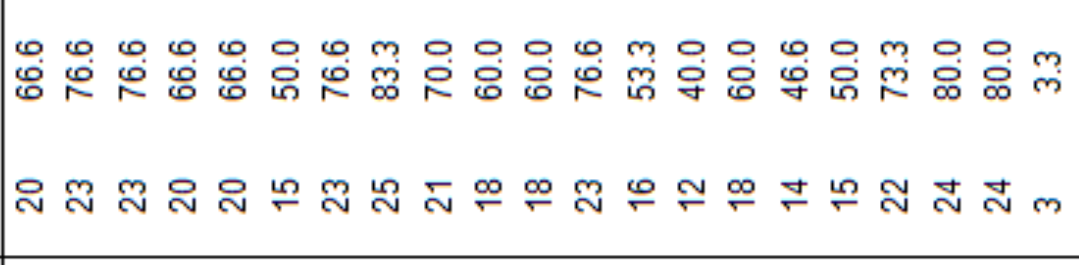 \\
\hline 资 & 芯 总 & 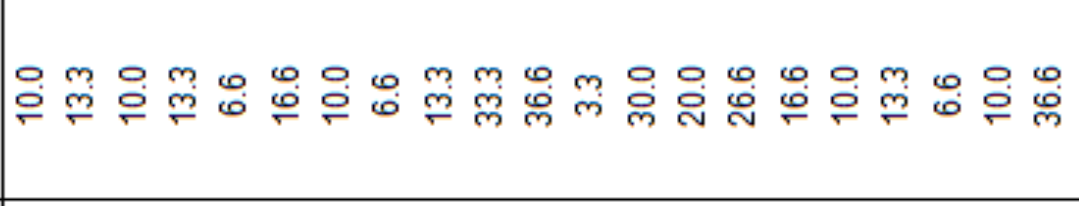 \\
\hline & 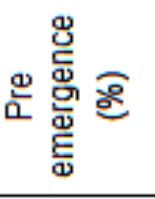 & m 웅 m \\
\hline 要, & & 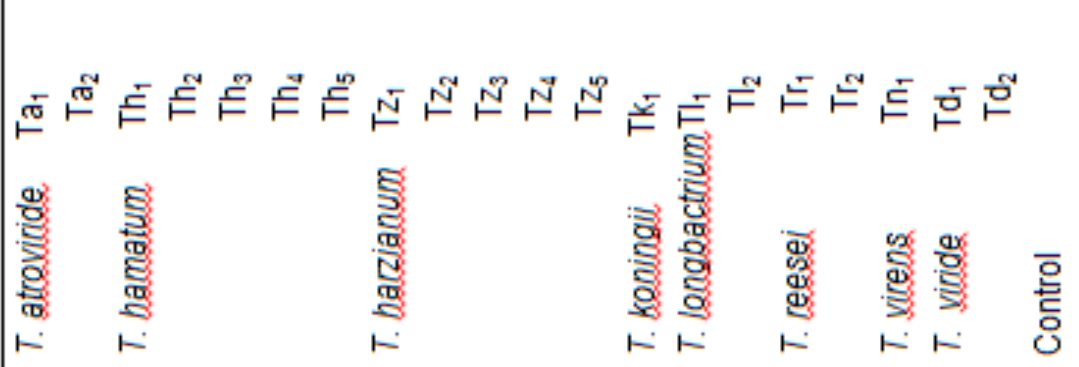 \\
\hline
\end{tabular}


Awad, et al.,

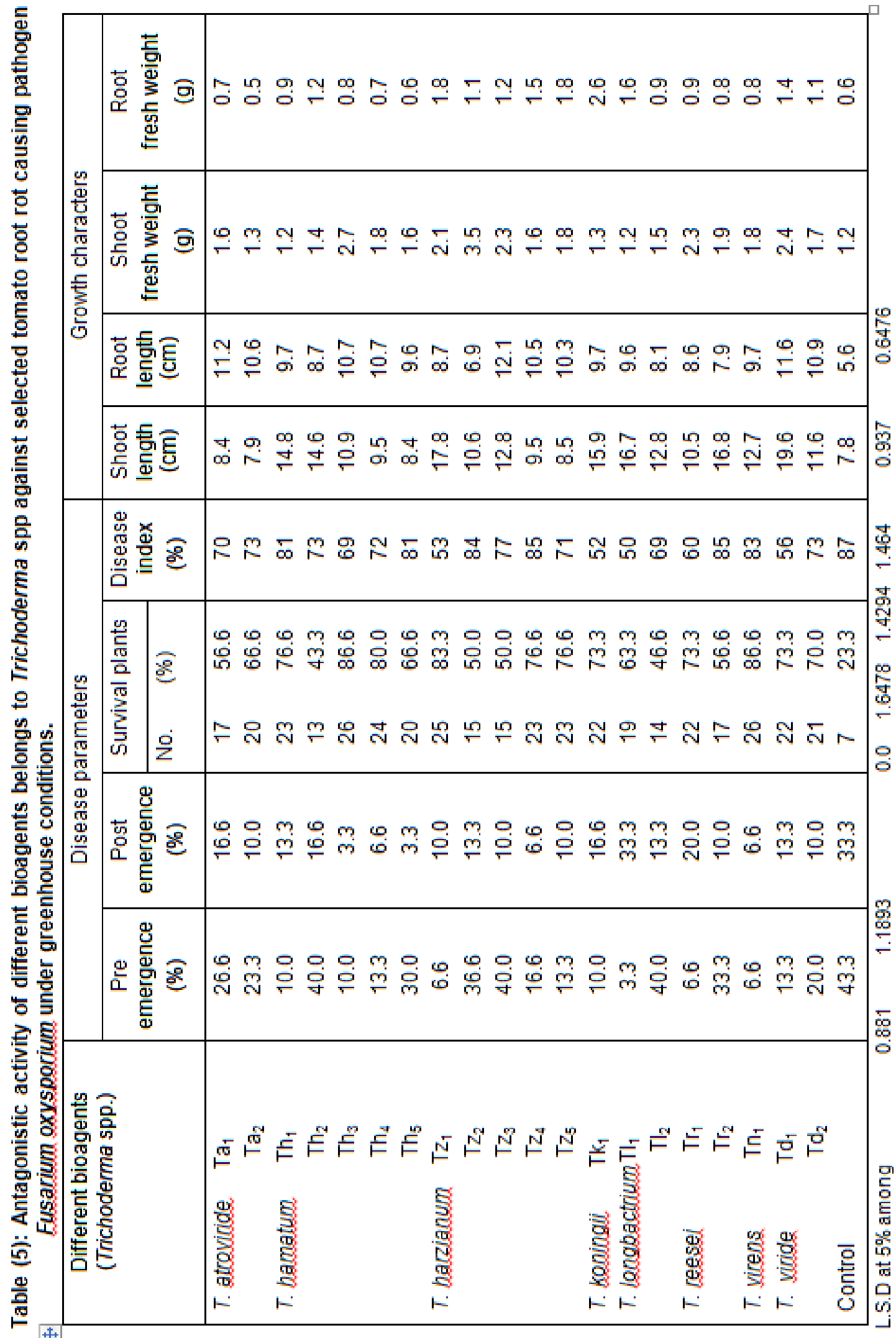




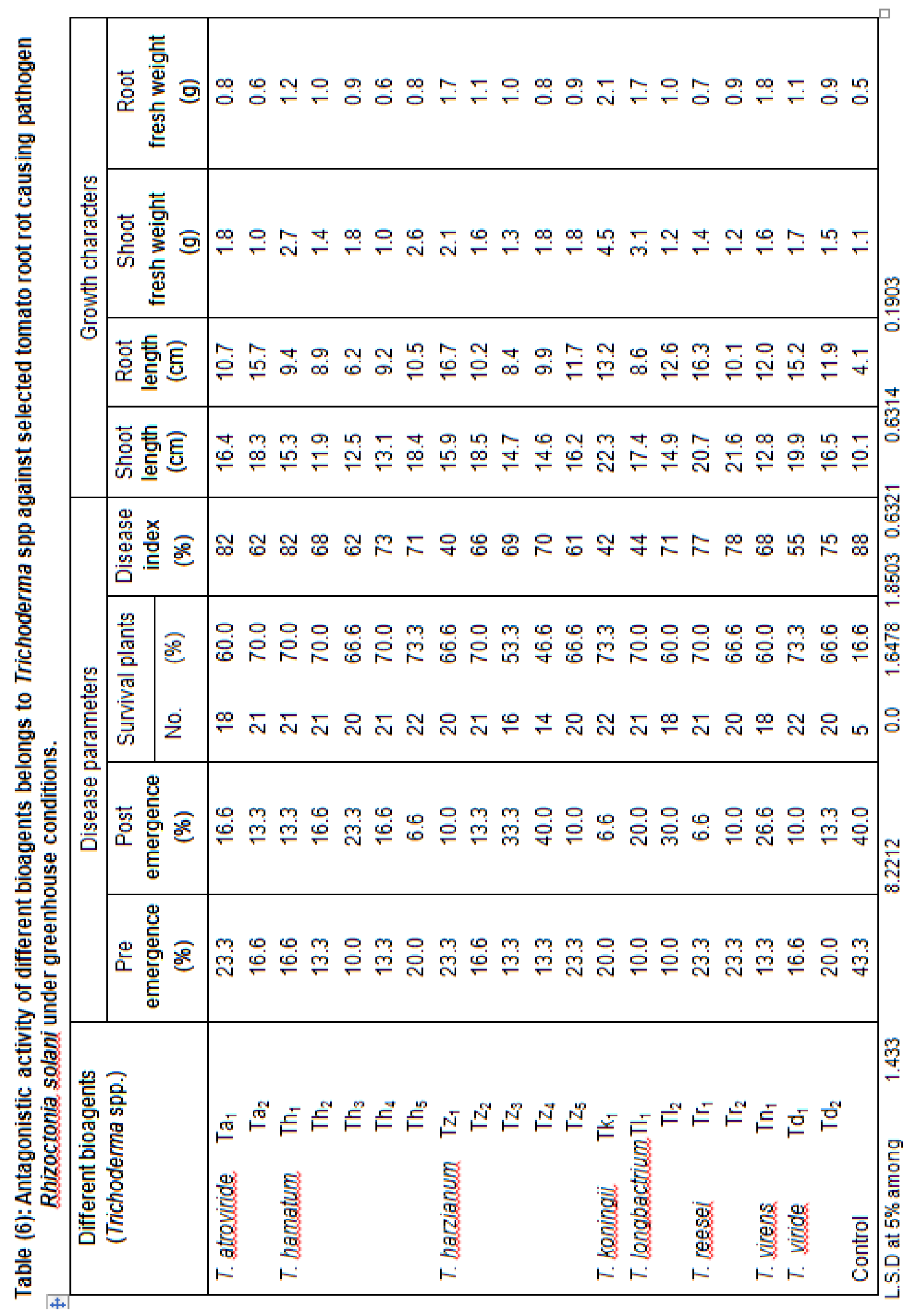


with $T$. koningii $\mathrm{Tk}_{1}(2.6 \mathrm{~g})$ whereas the highest shoot fresh weight was achieved by tomato plant previously treated with $T$. harzianum $\mathrm{Tz}_{2}(3.5 \mathrm{~g})$ compared to root fresh of control tomato $(0.6 \mathrm{~g})$ and its shoot fresh $(1.2 \mathrm{~g})$, respectively.

Data elucidated in Table (6), the percentage of the pre and post-emergence damping off reached 43.3 and $40.0 \%$ when the root rot tomato cultivar infected with $R$. solani. In addition, the number of survival untreated tomato plants was 5 and their percentage is $16.6 \%$. Treatment of tomato plants with different Trichoderma spp. greatly control the disease severity since $T$. longbactrium $\mathrm{Tl}_{1}$ and $\mathrm{Tl}_{2}$ decrease the preemergence damping off to $10 \%$ whereas $T$. hamatum $\mathrm{Th}_{5}, T$. koningii $\mathrm{Tk}_{1}$ and $T$. reesi $\mathrm{Tr}_{1}$ declined the post-emergence damping off to $6.6 \%$. The survival number was increased by three folds or more when the root rot disease was controlled by different Trichoderma spp.

Similarly, selected Trichoderma bioagents enhanced the growth yield of tomato plants either root or shoot lengths. Regarding to root and shoot weights, the root weight was increased by more than four folds after treatment of tomato seeds with $T$. koningii $\mathrm{Tk}_{1}$ and the shoot weight was nearly tripled by treatment of tomato seeds with $T$. longbactrium $\mathrm{Tl}_{1}, T$. harzianum $\mathrm{Tz}_{1}$ and $T$. virens $\mathrm{Tn}_{1}$ under greenhouse conditions.

In the present study, results of greenhouse experiments confirmed the previous finding of antagonistic activity of Trichoderma bioagents against root rot pathogens under laboratory conditions. Thus, $T$. harzianum $\mathrm{Tz}_{1}, T$. koningii $\mathrm{Tk}_{1}, T$. longbactrium $\mathrm{Tl}_{1}$ and $T$. viride $\mathrm{Td}_{1}$ are most potent bioagents for tomato root rot disease. Different strategies are applied to enhance the activity of these promising bioagents in an individual upcoming study.

\section{Discussion}

Tomato (Lycopersicon esculantum Mill), which belongs solanaceae family, is the most popular and economic vegetable crop in many parts of the world for its high nutritional value, richness in vitamins $A$ and $C$ and its multiplicity uses. Tomato plants are attacked with various diseases including bacterial diseases, fungal diseases, moth larvae and nematodes diseases and vial, viroid and phytoplasma diseases as well as miscellaneous diseases and disorders. Pathogenic fungi cause seedling dampingoff and root rots diseases which reduces both yield quality and quantity.

Two hundred and fifty nine fungal isolates were isolated from the diseased roots during 2012 and 2013 seasons including; Alternaria solani, $A$. chlamydosporum, A. porri, Camarosporum tassi, Fusarium oxysporum, $F$. chlamydosporum, F. semitectum, Gibberella godonii, Paecilomyces variotii, Rhizoctonia solani and Sclerotinia $s p$. All these fungal isolates aren't causative agents of root rot disease but some of them are superficial contaminants of root and others are candidates of soil deterioration. These data agree with previous findings (Erol and Tunali 2009). Al-Askar et al. (2014) concluded that tomato seeds were associated with a large number of seed-borne mycoflora. They isolated 57 fungal borne seeds species belonging to 30 genera from tomato plants including i.e. Alternaria alternata, Fusarium oxysporum, $F$. equiseti, $F$. solani, $F$. verticillioides, Pythium lycopersici, Verticillium dahliae, Macrophomina phaseolina and Rhizoctonia solani.

Similarly, twenty five strains of $F$. oxysporum were isolated from 25 infected roots of tomato plants that collected from different geographic regions of western Iran. Based on the morphological features, 18 isolates were identified to two known Fusarium species complex (FOSC), namely $F$. oxysporum and $F$. redolens. In addition, seven isolates were classified into two known Gibberella fujikuroi species complex (GFSC), namely $G$. proliferatum and $G$. verticillioides (Chehri, 2016). The 
management of soil-borne plant pathogens is particularly complex because these organisms live in or near the dynamic environment of the rhizosphere, and can frequently survive a long period in soil through the formation of resistant survival structures (El-Gamal et al., 2016).

The pathgenicity studies revealed the potent pathogenicity of $A$. solani, $F$. oxysporum and $R$. solani against healthy and informal tomato roots either wounded or unwounded. Previous studies succeeded to isolate fungal pathogens causing root rot disease. (El-Mohamedy, 2014). Rhizoctonia solani is one of the phytopathogens that attack tomatoes cultivated under greenhouse conditions, causing dampingoff, root rot and crown rot. Root rot disease caused by $R$. solani Kuhn is the most destructive disease of tomato whereas other fungal pathogens cause wilts and stem cankers of tomato seedlings (Al Elzerjawi, 2015). Since that pathogen is soil-borne, it can live in the soil for long periods of time, and therefore rotational cropping is not a useful control method. It can also spread through infected dead plant material making the cleaning up process at the end of the season is critical. Therefore, planting of resistant varieties is one strategy used for controlling F. oxysporum wilting (Grahovac et al., 2011).

In the present study, artificially infected soil had no significant influence on seed germination, but it cause plant wilting after emergence. Contrary, TFM1-TFM6 isolates failed to infect plants and have no significant influence on emergence or growing in comparison to control (Ignjatov et al., 2012).

In a previous study, $F$. solani and $R$. solani isolates had the pathogenic effect against several commercial tomato cultivars includes; Ace, Brmodro, Castle Rock and Super-Marmade. $R$. solani was isolated as the predominant damping-off fungus with highest frequency of $60.0 \%$. Not only the incidence of damping off disease caused by F. solani was in the range of 2.3 to $50.0 \%$, while the incidence of root rot disease was the ranged of 3.3 to $36.3 \%$.The incidence of damping off disease caused by $R$. solani was in the range of 11.1 to $35.0 \%$, while root rot disease was in the range of 3.3 to 38.5\% (Haggag and El- Gamal, 2012). Damping off is caused because pathogen invades the vascular tissues and grows in the vascular bundles, inhibits water flow causing wilting and ultimately leading to death of plant. Vessel walls of tomato plant often are coated in an amorphous electronopaque material and this material includes xylem parenchyma, pit cavities and encrusts intertracheary pit membrane. At least, infection is accompanied by the gradual death of xylem parenchyma cells throughout secreting its metabolites; enzyme, growthregulating compounds and gummosis (Amini 2009).

Results revealed the superiority of four antagonists $T$. harzianum $\mathrm{Tz}_{1}, T$. koningii $\mathrm{Tk}_{1}, T$. longbactrium $\mathrm{Tl}_{1}$ and $T$. viride $\mathrm{Td}_{1}$ against three selected fungal pathogens; Alternaria solani, Fusarium oxysporum and Rhizoctonia solani either in vitro or vivo are Previous reports indicated that $T$. asperellum had a biological control activity over Phytophthora capsici, P. megakarya and Rhizoctonia solani (Segarra et al., 2012). About $90 \%$ of the formulations of antagonistic fungi commercially used for biological control treatment on different Trichoderma species including; $T$. harzianum, T. virens and T. viride (Kaewchai et al., 2009). This interesting specie is characterized by its antifungal metabolites including trichosporin, cyclosporine, peptaibols, and cyclonerodiol derivatives (Reino et al., 2008).

A first comparative analysis within Trichoderma spp and model organisms with publicly available genomes (Fusarium, Neurospora, Colletotrichum, Magnaporthe, Clonostachys and Verticillium) suggested that $T$. gamsii $T 6085$ contains a large number of specific carbohydrate-active enzymes (CAZy) such as GH30, GH2, 
GH13, and GH5, ceratoulmin hydrophobin, proteinase inhibitor, peptidases, such as G1 and S53, and glucose/ribitol dehydrogenase enzymes (Karlsson et al., 2015). The genome sequence of $T$. gamsii T6085 represents a new resource that is useful for further research into the genetic bases of Fusarium head blight biological control by Trichoderma species.

Khalili et al., (2016) revealed the growth rates of Macrophomina phaseolina when treated with Trichoderma harzianum isolates; T2, T10 and T12 exhibited growth inhibition and showed exceptional hyperparasitism against its colonies. Evaluation of the inhibition zones surrounding the T12, T2 and T10 isolates revealed the inhibition of the $M$. phaseolina by $72.31 \%, 45.23 \%$ and $44.13 \%$, respectively. The results also indicated that field pots treated with suspensions of $T$. harzianum (T2, T10 and T12) showed improved root and stem lengths, as well as a general increase in seed weight. Competition, antibiosis, and mycoparasitism mediated by hydrolytic enzymes are classic mechanisms used by different Trichoderma spp to biocontrol various plant diseases (Munir et al., 2014).

\section{REFERENCES}

Abdel-Monaim M. F. Abdel-Gaid M. A. and Hanaa A. H. Armanious (2012). Impact of chemical inducers on vigor, yield, fruit quality and controlling root rot /wilt diseases of tomatoes in New Valley, Egypt Scholarly. Journal of Agricultural Science, 2(8): 137-146.

Al-Askar, A.A., K.M. Ghoneem, Y.M. Rashad, W.M. Abdulkhair, E.E. Hafez, Y.M. Shabana and Z.A. Baka (2014). Occurrence and distribution of tomato seeds borne mycoflora in Saudi Arabia and its correlation with the climatic variables. Microbial biotechnology, 7 (6):556-569.

AL-Elzerjawi, N. H. M. (2015). Assessment the Effect of some Bio Control Agents and Organically-ITM for Controlling Root rot and Damping-off Diseases of Tomato
(Lycopersicon esculentum) Mill Caused by Rhizoctonia solani Kühn. International Journal of Scientific \& Engineering Research, Volume 6, Issue 1, ISSN 2229-5518.

Amini, J. (2009). Physiological race of Fusarium oxysporum f. sp. lycopersici in Kurdistan province of Iran and reaction of some tomato cultivars to race 1 of pathogen. Plant Pathol. J, 8:68-73.

Barnett, H.L. and B.B. Hunter (1972). Illustrated genera of imperfect fungi. Minnesota Burges Publ., p. 241.

Benítez, T., M. R. Ana, M. L. Carmen and C. C. Antonio (2004). Biocontrol mechanisms of Trichoderma strains. International Microbiology, 7:249-260.

Bissett, J. (1991). A revision of the genus Trichoderma. II. Inferagenetic classification. Can. J. Bot., 69: 23572372.

Chehri, K. (2016). Molecular identification of pathogenic Fusarium species, the causal agents of tomato wilt in western Iran. Journal of Plant Protection Research, 56 (2):143-148.

Domsch, K. H., W. Games and T. H. Anderson (1980). Compendium of soil fungi. London, Academic Press., 1: 859.

Elad, Y., Y. Hadar, E. Hadar, I. Chet and Y. Henis (1981). Biological control of white rot (Sclerotinia sclerotiorum) of pea (Pisum sativum L.). Journal of Research, Punjab Agricultural University., 39(3): 382-390.

El-Gamal, N. G., N. S. Abeer, R. H. Eman and S. S. Heba (2016). Improvement of lytic enzymes producing Pseudomonas fluorescens and Bacillus subtilis isolates for enhancing their biocontrol potential against root rot disease in tomato plants. Research Journal of Pharmaceutical, Biological and Chemical Sciences, 7(1): 0975-8585.

El-Mohamedy, R.S. (2014). Control of rootrot disease of tomato plants caused by Fusarium solani, Rhizoctonia solani and Sclerotium rolfsii using different chemical plant resistance inducers. 
Tunisian J. of Plant Protection, 9(1): 4555.

El-Mougy, N., M. Abdel-Kader, M. Aly and S. Lashin (2012). Application of fungicides alternatives as seed treatment for controlling root rot of some vegetables in pot experiments. Advances in Life Sciences, 2 (3):57-64.

Erol, F.Y. and B. Tunali (2009). Determination of root and crown rot diseases in tomato growing area of Samsun province. Acta Hort. (ISHS), 808:65-70.

Gaigole, A.H., G.N. Wagh and A.C. Khadse (2011). Antifungal activity of Trichoderma species against soil borne pathogen. Asiatic Journal of Biotechnology Resources, 2(04):461465.

Grahovac, M., D. Inđić, B. Tanović, S. Lazić, S. Vuković, J. Hrustić and S. Gvozdenac (2011). Integrated management of causal agents of postharvest fruit rot of apple. Pesticidi i fitomedicina, 26 (4):289-299.

Haggag, K. H.E. and N. G. El-Gamal (2012). In vitro Study on Fusarium solani and Rhizoctonia solani Isolates Causing the Damping Off and Root Rot Diseases in Tomatoes. Nature and Science, 10(11):16-25, ISSN: 1545-0740.

Harman, G. E., C. R. Howell, A. Viterbo, I. Chet and M. Lorito (2004). Trichoderma species-opportunistic, avirulent plant symbionts. Nature Review of Microbiology, 2:43-56.

Ignjatov, M., D. Milosevic, Z. Nikolic, J. Gvozdanovic-Varga, D. Jovicic and G. Zdjelar (2012). Fusarium oxysporum as causal agent of tomato wilt and fruit rot. 27(1): 25-31.

Kaewchai, S., K. Soytong and K. Hyde (2009). Mycofungicides and fungal biofertilizers. Fungal diversity, 38:25-50.

Karlsson, M., M.B. Durling, J. Choi, C. Kosawang, G. Lackner, G.D. Tzelepis, K. Nygren, M.K. Dubey, N. Kamou and A. Levasseur (2015). Insights on the evolution of mycoparasitism from the genome of Clonostachys rosea. Genome Biology and Evolution, 7 (2):465-480.

Khalili, E., M.A. Javed, F. Huyop, S. Rayatpanah, S. Jamshidi and R.A. Wahab (2016). Evaluation of Trichoderma isolates as potential biological control agent against soybean charcoal rot disease caused by Macrophomina phaseolina. Biotechnology \& Biotechnological Equipment, 30 (3):479-488.

Morsy, E. M., K. A. Abdel-Kawi and M. N. A. Khalil (2009). Efficiency of Trichoderma viride and Bacillus subtilis as Biocontrol Agents gainst Fusarium solani on Tomato Plants Egyptian Journal of Phytopathology. Vol. 37, No. 1, pp. 4757.

Munir, S., Q. Jamal, K. Bano, S.K. Sherwani, M.N. Abbas, S. Azam, A. Kan, S. Ali and M. Anees (2014). Trichoderma and biocontrol genes: Review. Scientia, 2 (2):40-45.

Reino, J.L., R.F. Guerrero, R. HernándezGalán and I.G. Collado (2008). Secondary metabolites from species of the biocontrol agent Trichoderma. Phytochemistry Reviews, 7 (1):89-123.

Rifai, M. A. (1969). A revision of the genus Trichoderma. Common welth Mycol. Inst. Mycol. Papers No. 116. p. 55.

Segarra, G., M. Avilés, E. Casanova, C. Borrero and I. Trillas (2012). Effectiveness of biological control of Phytophthora capsici in pepper by Trichoderma asperellum strain T34. Phytopathologia Mediterranea:77-83.

Zaghloul, R.A., Ehsan A. Hanafy, N. A. Neweigy and Neamat A. Khalifa (2007). Application of biofertilization and biological control for tomato production. Conference of Microbiology; (18-22): 198-212.

Zhou, T. and R.T. Reeleder (1990). Selection of strains of Epicoccum purpurascens and improved biocontrol of Sclerotinia sclerotiurum. Can. J. Microbiol., 36: 754- 759. 


\section{المكافحة الحيوية لعفن جذور الطماطم باستخدام فطريات الترايكودرما}

محمد احمد عوض(1) ، السعيد زكى خليفة(1) ، محى الدين زهير الفولى (2) ،

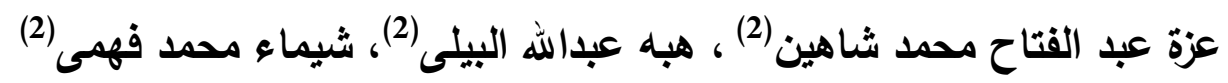

(1)

(2) قسم الميكروبيولوجيا الاشعاعية- المركز القومى لبحوث وتكنولوجيا الاشعاعة الزية هيئة الطاقة الذرية

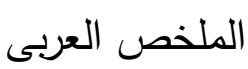

تم عزل عدد مائتين وتسع وخمسين عزلة فطرية من جذور نبات الطماطم المصابة التى تم تجميعها من ستة

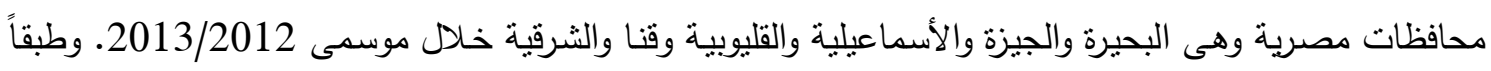

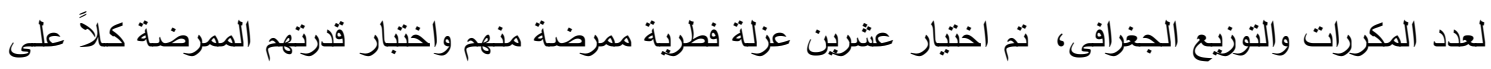

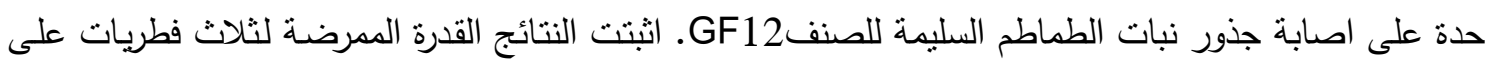
احداث الأصابة بمرض عفن جذور الطماطم وهم:

Fuarium oxysporum No.1 and Rhizoctoina solani, Alternaria solani No.1

وبدراسة التضـاد الحيوي لعدد من فطريات التريكودرما المعزولة من تربـة الريزوسفير على التلات فطريات الممرضة والمحدثة لمرض عفن جذور الطماطم فى المعمل، اسنطاعت فطريات التريكودرما تقليل نمو الفطريات

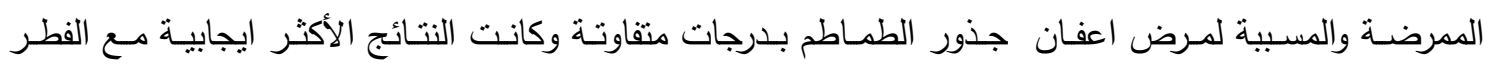
الممرض (ما بين 46.7\% ،85.2\%). وبدراسة الككافحة الحيوية لفطريات التريكودرما للحد من الأصـابة الحقلية

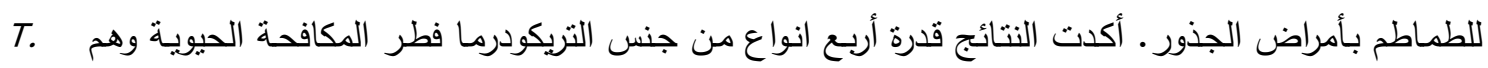
harzianum $\mathrm{Tz}_{1}$, T. koningii $\mathrm{Tk}_{1}$, T. longbactrium $\mathrm{Tl}_{1}$ and $T$. viride $\mathrm{Td}_{1}$ باستخدام وسائل منتوعة فى دراسة متقدمة نالية. 